\title{
Narradores de Javé o filme e suas metáforas biblieas
}

\section{Yahweh narrators the film and its biblical metaphors}

\author{
Cláudio Vianney Malzoni*
}

Recebido em: 06/06/2020. Aceito em: 22/06/2020.

Resumo: "Narradores de Javé", um filme de 2003, conta a história de um povoado do interior nordestino que estava para ser inundado pela construção de uma barragem. Para salvá-lo, seus moradores querem escrever as histórias dos antepassados para que assim o lugar seja declarado patrimônio histórico. O filme serve para suscitar o debate em várias áreas, dentre as quais a dos estudos bíblicos, mesmo porque o filme está repleto de metáforas bíblicas, a começar por seu nome. No presente artigo, quer se mostrar quais temas, no conjunto dos estudos bíblicos, poderiam ser tratados a partir do filme. Para isso, são levantadas algumas possibilidades a partir de algumas cenas do filme ou de algumas de suas características. Ao final, diversos temas próprios dos estudos bíblicos apareceram elencados, mostrando sim que "Narradores de Javé" ajuda no debate também nesta área de conhecimento.

Palavras-chave: Narradores de Javé. Narratologia bíblica. Leitura popular da Bíblia.

Abstract: "Narradores de Javé", a 2003 film, tells the story of a village in the Northeast region of Brazil that was about to be flooded by the construction of a dam. To save it, its residents want to write the stories of their ancestors so that the place can be declared a historical heritage. The film serves to provoke debate in several areas, including that of biblical studies, even because the film is full of biblical metaphors, starting with its name.

* Doutor em Ciências Bíblicas (École Biblique et Archéologique Française de Jérusalem, EBAF, Jerusalém, 2002). Mestre em Ciências Bíblicas (Pontificium Institutum Biblicum de Urbe, PIB, Roma, 1997). Bacharel em Teologia (Faculdade Jesuíta de Filosofia e Teologia, FAJE, Belo Horizonte, MG, 1992). Bacharel em Filosofia (Faculdade Jesuíta de Filosofia e Teologia, FAJE, Belo Horizonte, MG, (1987). Graduação em Licenciatura Plena em Geografia (Faculdade de Filosofia Ciências e Letras de Sorocaba, FFCLS, Sorocaba, SP, 1983).

E-mail: cvmalzoni@hotmail.com 
In this article, we want to show which themes, in the set of biblical studies, could be treated from the film. For that, some possibilities are raised from some scenes of the film or some of its characteristics. In the end, several themes specific to biblical studies appeared listed, showing that "Narradores de Javé" also helps in the debate in this area of knowledge.

Keywords: Narradores de Javé. Biblical narrative. Popular Bible Reading.

\section{Introdução}

"Narradores de Javé" é um clássico do cinema brasileiro. O filme é de 2003 e foi dirigido por Eliane Caffé. O filme conta a história dos moradores do Vale de Javé que tentam defender o lugar onde vivem diante da ameaça de inundação provocada pela construção de uma barragem. O meio de defesa encontrado por eles é provar que o lugar é patrimônio histórico e, para isso, pretendem colocar por escrito as histórias das origens do povoado. Isso, no entanto, esbarra em outra dificuldade: a maioria dos habitantes de Javé é iletrada. Para escrever o livro, eles recorrem a Antônio Biá, que tinha sido expulso do povoado e vivia em suas cercanias. Ele começa então a ouvir as histórias contadas pelas pessoas a fim de registrá-las por escrito.

O filme pode ser visto a partir de diversos ângulos. Pode ser assistido como diversão em um momento de lazer, como também pode servir como subsídio para o debate em salas de aula de cursos tanto em nível acadêmico quanto popular, em diversas disciplinas. As ligações entre a Bíblia e o filme são inúmeras e facilitam sua utilização como subsídio didático em cursos bíblicos.

A lista dos laços que unem o filme à Bíblia começa pelo nome do lugar onde está situado o povoado-cenário do filme: Vale de Javé. Daí, o título do filme: "Narradores de Javé". Esse nome já é suficiente para trazer a Bíblia à memória do espectador do filme. Há outros tantos pontos de contato entre o filme e a Bíblia e aqui pretendem-se colocar em destaque quatro. O primeiro é de onde surge a necessidade de escrever; o segundo é o modo de narrar atualizando o narrado; o terceiro é a valorização do ponto de vista pessoal que é dado às narrativas, e o quarto a afirmação de que a transmissão escrita das narrativas não substitui sua transmissão oral. Esses quatro pontos serão tratados a seguir, precedidos de uma apresentação mais detalhada do filme. 


\section{Filme}

"Narradores de Javé" tem duração de 100 minutos. O roteiro é de Eliane Caffé e Luis Alberto Abreu. A direção é da cineasta brasileira Eliane Caffé. ${ }^{1} \mathrm{O}$ elenco do filme conta com nomes conhecidos do meio artístico nacional, ganhando destaque as atuações de José Dumont (Antônio Biá), Nelson Xavier (Zaqueu), Rui Resende (Vado), Gero Camilo (Firmino), Nelson Dantas (Vicentino), e Luci Pereira (Deodora). O filme foi rodado na cidade baiana de Gameleira da Lapa, de junho a setembro de $2001 .^{2}$

A diretora, Eliane Caffé, nasceu em 13 de agosto de 1961, na cidade de São Paulo. ${ }^{3}$ Concluiu a graduação em psicologia na Pontifícia Universidade Católica de São Paulo, em 1985, e fez mestrado no Instituto de Estética y Teoria de las Artes, da Universidade Autônoma de Madrid, Espanha, de 1991 a $1992 .{ }^{4}$

Entre o término da graduação em São Paulo e o mestrado em Madrid, Eliane esteve em Cuba, onde fez estudos de cinema, na Escola Internacional de Cine y TV de San Antonio de los Baños. De volta ao Brasil após o mestrado, dedicou-se à produção de curtas e longas-metragens e de séries para a TV. ${ }^{5}$

Antes de "Narradores de Javé", Eliane Caffé produziu o filme "Kenoma" (1998), e os curtas-metragens: "Caligrama" (1995) e "Arabesco" (1990). Depois, vieram "O sol do meio-dia" (2009) e "Era o Hotel Cambridge" (2016). Sua produção conta ainda com a série "O louco dos viadutos" (2009), produzido para a TV Cultura, e os documentários para TV: "Cidades sem janelas" (1994). "Milágrimas" (2006) e "A margem da paisagem". ${ }^{6}$

Em seu trabalho, Eliane vem alternando cenários de um Brasil rural e urbano. Neles, "é visível a experimentação com a narrativa

1 FILMOW. Narradores de Javé. Disponível em: <https://filmow.com/narradores-de-jave-t5459/ficha-tecnica/>.

2 NARRADORES DE JAVÉ. Disponível em: <http://www.adorocinema.com/filmes/ filme-52182/curiosidades/>.

3 PAPO DE CINEMA. Eliane Caffé. Disponível em: <https://www.papodecinema.com. br/artistas/eliane-caffe/biografia/>.

4 ELIANE CAFFÉ. Disponível em: <http://www.elianecaffe.com/curriculo.html>.

5 ELIANE CAFFÉ. Disponível em: <http://www.elianecaffe.com/curriculo.html>.

6 ELIANE CAFFÉ. Disponível em: <http://www.elianecaffe.com/curriculo.html>. 
que interage com personagens reais e agrega repertórios de seus universos de vida como coletivos com voz própria". ${ }^{7}$ Assim foi com "Narradores de Javé": ao lado de um elenco de artistas profissionais, atuaram também moradores de Gameleira da Lapa, dando maior vivacidade ao filme. ${ }^{8}$ A diretora também afirma que muito do que vê no filme, sobretudo, nas falas das personagens, provém da trajetória de vida do ator José Dumont, razão pela qual ela o considera como coautor do filme. ${ }^{9}$

O roteiro do filme tem seu ponto de partida em uma história real acontecida no interior baiano: no posto dos Correios de uma pequena cidade, o único funcionário escrevia cartas na tentativa de evitar que o posto fechasse. ${ }^{10}$

"Narradores de Javé” ganhou diversos prêmios em festivais de cinema no Brasil e fora do Brasil: no Canadá, Uruguai, México, Bélgica e Suíça. Os prêmios vieram para as categorias de melhor filme, melhor direção, melhor montagem e som, ator, atriz, ator coadjuvante e atriz coadjuvante. ${ }^{11}$

Pesquisando "Narradores de Javé" no Catálogo de Teses e Dissertações da CAPES, aparecem treze entradas, todas elas de dissertações. ${ }^{12}$ Nenhuma dessas dissertações foi defendida na Área de Avaliação 44 da CAPES, de Ciências da Religião e Teologia. No entanto, o filme bem pode ser objeto de pesquisa nessa Área. A modo de exemplo, serão mostrados alguns aspectos do filme que poderiam ser tratados a partir da subárea Tradições e Escrituras Sagradas, que é apenas uma entre outras da Área Ciências da Religião e Teologia, a começar pela questão de onde surge a necessidade de escrever.

$7 \quad$ ELIANE CAFFÉ. Disponível em: <http://www.elianecaffe.com/curriculo.html>.

8 CARDOSO, Heloisa Helena Pacheco. Narradores de Javé: história, imagens, percepções. Fênix: Revista de História e Estudos Culturais. Uberlândia, v. 5, n. 2, p. 1-11, 2008, p. 11.

9 ARANTES, Silvana. Episódio real inspira "Narradores de Javé". In: Folha de São Paulo, Ilustrada, 17/10/2003. Disponível em: <https://www1.folha.uol.com.br/folha/ ilustrada/ult90u37926.shtml>.

10 ARANTES, Silvana. Episódio real inspira "Narradores de Javé". In: Folha de São Paulo, Ilustrada, 17/10/2003. Disponível em: <https://www1.folha.uol.com.br/folha/ ilustrada/ult90u37926.shtml>.

11 ELIANE CAFFÉ. Disponível em: <http://www.elianecaffe.com/curriculo.html>.

12 CAPES. Catálogo de teses e dissertações. Disponível em: <https://catalogodeteses. capes.gov.br/catalogo-teses/\#!/>. 


\section{A necessidade de escrever}

No filme, a necessidade de escrever as gloriosas histórias de Javé aparece quando a comunidade se sente ameaçada. O povoado está para ser inundado por causa da construção de uma barragem e seus habitantes buscam um modo de interromper esse projeto. $\mathrm{O}$ drama dos moradores de Javé não é imaginário, pois muitos brasileiros já vivenciaram esse drama e isso ajudar a criar uma empatia dos espectadores com os atores.

Os moradores do povoado precisam provar cientificamente a importância do lugar e chegam à conclusão que essa importância está nas histórias contadas por seus antepassados, desde as origens, quando expulsos de suas terras pelo rei de Portugal, peregrinam em busca de outro local onde pudessem se estabelecer, até chegarem ao Vale de Javé.

Agora, a comunidade vive uma nova ameaça de expulsão, que faz surgir a necessidade da escrita, ou da passagem da tradição oral à tradição escrita. O problema é que, em sua maioria, os habitantes do lugar são iletrados e acabam confiando a Antônio Biá a tarefa de escrever o livro dos grandes feitos de Javé. Ao longo do filme, Antônio Biá profere algumas máximas sobre as diferenças entre a linguagem oral e a linguagem escrita, como essa: "A história é de vocês, mas a escrita é minha". ${ }^{13}$

No método histórico-crítico de exegese bíblica, em seu modelo mais clássico, o estudo da história das tradições tinha lugar de destaque. Esse estudo se dividiu em dois métodos, mais complementares que opostos entre si. O primeiro foi o da Überlieferungsgeschichte da exegese alemã, que se ocupou, sobretudo, com o Pentateuco. Esse método aborda o processo da formação da tradição em todas as suas fases, desde a origem pré-literária ao surgimento de pequenas unidades e até sua integração em conjuntos mais vastos, privilegiando, contudo, a fase intermediária. O centro de interesse é a questão de saber se, nessa

13 Antônio Biá é uma personagem complexa no filme. Ora, é a caricatura do intelectual que despreza o povo; no frontispício de sua casa, está escrito: "Proibida a entrada de analfabetos". Ora é a representação da consciência crítica daquelas pessoas, como quando diz: "O que nós somos é só um povinho ignorante que quase não escreve o próprio nome, mas inventa histórias de grandeza para esquecer a vidinha rala, sem futuro nenhum". De qualquer modo, ele não pode escapar do fato de que ele próprio pertence àquela comunidade. No dizer de Antônio Ribeiro Júnior e Márcia Feitosa, "as memórias de Biá também passam a pertencer à memória coletiva da comunidade" (RIBEIRO Júnior, Antônio Carlos Araújo; FEITOSA, Márcia Manir Miguel. Narradores de Javé: memórias e identidades polifônicas no cinema brasileiro. In: Resgate: Revista Interdisciplinar de Cultura. Campinas, v. 25, n. 1, p. 67-88, 2017; p. 84. 
fase intermediária, as tradições já se apresentavam na forma escrita ou estavam ainda na forma oral. O segundo ramo da história das tradições é o Traditio-Historical Method da exegese escandinava, que atribui um peso maior ao estágio da transmissão oral. Essa, tem tal importância que mesmo as tradições postas por escrito continuariam a ser influenciadas pela transmissão oral. É isso que explicaria as variações e diferenças de estilo presentes, por exemplo, no Pentateuco. Em sua origem, esse método postulava que a transmissão oral era extremamente fiel ao fundamental, o que, posteriormente, passou a ser contestado, a partir de uma nova visão do papel do narrador que, "a cada vez que 'narra' recompõe livre e espontaneamente sua narração". ${ }^{14}$

É possível que na Bíblia tenha acontecido algo semelhante ao que é retratado no filme. A necessidade de escrever tenha surgido frente a novas situações desafiadoras. As experiências do exílio na Babilônia e, de modo especial, da volta dos exilados podem ter sido os catalisadores das tradições anteriores de outras experiências como a da servidão no Egito e da travessia do deserto rumo à Terra Prometida.

\section{Narrar atualizando}

Não dá para ter certeza se a escrita das narrativas bíblicas surgiu, assim como no filme, de uma necessidade premente, e, em caso afirmativo, em que extensão. Por outro lado, é mais fácil perceber que o interesse pelas tradições do passado tem a ver com o presente, o que "Narradores de Javé" retrata muito bem.

Para escrever o livro da salvação, Antônio Biá vai em busca das histórias contadas pelas pessoas do povoado. Cada qual conta a história a partir de um ponto de vista que lhe é próprio, implicando sua própria pessoa na história narrada. É assim que, para o Sr. Vicentino Indalécio da Rocha, o Indalécio que conduziu o povo até o Vale de Javé era um homem sistemático como ele próprio, para citar apenas um exemplo, aliás, o primeiro a aparecer no filme.

Essa característica do filme é apontada pela professora de história Heloisa Cardoso com as seguintes palavras:

14 LIPIŃSKI, Édouard. Tradições, História das. In: Dicionário enciclopédico da Bíblia. São Paulo: Loyola; Paulus; Paulinas, 2013. p. 1325. 
Indalécio, Maria Dina, Indalêo, e outros personagens criados nas narrativas dos moradores, projetam eles mesmos na realidade social, interpretando pela linguagem as redes de relações construídas e onde se inserem. O momento de crise, vivido como possibilidade concreta de desaparecimento de Javé pela inundação, leva os moradores a reconstruírem o passado atribuindo a ele outras significações. ${ }^{15}$

A narrativa histórica se volta para o passado, estando inserida no presente e com vistas ao futuro. O que ocorreu outrora é exemplo a ser seguido ou a ser evitado, o que mostra o lado pragmático de toda narrativa. Nesse sentido, a história é campo, por excelência, de conflito: o conflito das interpretações que disputam entre si em busca de reconhecimento. ${ }^{16}$

Em entrevista à Revista Época, Eliane Caffé foi perguntada sobre a questão se o conflito de versões mostrado no filme não aboliria a possibilidade de uma verdade absoluta ou mesmo não mostraria como os povos constroem para si imagens e mitos sem compromisso com a objetividade. Em sua resposta afirmou:

Nosso objetivo era mostrar o choque de versões entre contadores de histórias e trabalhar em cima da riqueza da narração oral. Fizemos três viagens ao sertão, pesquisamos histórias dos lugares com os moradores e vimos a riqueza de versões. Queríamos com isso relativizar o caráter oficial do texto histórico e mostrar o jogo de interesses contido nas versões oficiais. Se a História do Brasil fosse contada pelos negros, seria uma outra História e com outras datas comemorativas. ${ }^{17}$

15 CARDOSO, 2008, p. 11.

16 Norma Côrtes, professora de história, aborda a questão das múltiplas narrativas presentes no filme a partir de outro viés. Ela observa que a história tem sido objeto de humor na cultura brasileira, e escreve: "a brincadeira de desmanchar fronteiras entre realidade histórica e ironia ficcional foi radicalizada em Narradores de Javé [...] Confundindo vida e arte, esse filme consiste num caleidoscópio com variados graus de narrativas em que verdade e simulacro coabitam em inusitada harmonia" (CÔRTES, Norma. História, memória e derrisão em Narradores de Javé. Revue Nuevo Mundo Nuevos Mundos [online], 20 abr. 2010. Disponível em: <https://journals.openedition. org/nuevomundo/59591>).

17 EM ENTREVISTA, cineasta Eliane Caffé fala do seu segundo longa, Narradores de Javé. Revista Época, Rio de Janeiro, Globo Editores, edição 296, 19 jan. 2004. Disponível em: <http://revistaepoca.globo.com/Revista/Epoca/0,,EDG62255-5856,00-EM +ENTREVISTA+CINEASTA+ELIANE+CAFFE+FALA+DO+SEU+SEGUNDO+LONG A+INARRADORES+D.html>. Encontrei a referência a essa entrevista no artigo de Heloisa Cardoso (2008, p. 7-8). 
A atualização dos textos bíblicos é parte integrante do método da leitura popular da Bíblia, que acontece nos círculos bíblicos. Isso se dá, sobretudo, porque o método começa com a recordação da vida, fazendo com que a leitura do texto bíblico que vem a seguir seja feita na perspectiva de sua importância para o presente, ou seja, em vista de sua atualização. Em um locus clássico a respeito do método da leitura popular da Bíblia, o mestre Carlos Mesters toma como base a perícope dos discípulos de Emaús, mostrando como Jesus parte da vida para depois se referir à Escritura (Lc 24,13-35). Mesters divide esse método em três momentos: (1) reflexão sobre a realidade; (2) estudo da própria Bíblia; (3) vivência comunitária da fé na ressurreição. ${ }^{18}$

O texto utilizado por Mesters para fundamentar o método da leitura popular da Bíblia mostra como o narrar atualizando é intrínseco à própria Bíblia, cujos autores, sem cessar, estão sempre retomando textos mais antigos, às vezes para afirmar a mesma coisa, outras vezes para afirmar coisas completamente diferentes; às vezes para lhes dar uma nova significação, outras para reapresentá-los em sua significação original, mas com uma nova configuração.

Esse fenômeno das múltiplas citações no interior da própria Bíblia, Robert Alter chama de "seu caráter fortemente alusivo". ${ }^{19}$ Nesse texto, Alter está se referindo à Bíblia hebraica. Quando se leva em consideração a Bíblia cristã, com as inúmeras referências ao Antigo Testamento no Novo Testamento e internamente no próprio Novo Testamento, com uns escritos referindo-se a outros, essa característica da Bíblia só pode ser expressa superlativamente. Alter dá como exemplo desse caráter alusivo da Bíblia hebraica o modo como a história de Rute retoma elementos presentes na história de Abraão:

Ela coloca Rute como uma mãe fundadora, em correspondência simétrica com Abraão, o pai fundador. Também Rute vem de um país estrangeiro para o Leste, para estabelecer-se na Terra Prometida. [...] a própria palavra inicial de Deus a Abraão. Lekh, "Vai-te" (raiz halak), ou simplesmente "vai", torna-se uma palavra-chave temática importante, estrategicamente reiterada na história de Rute: somos repetidamente lembrados de que sua "saída" de Moabe é, paradoxalmente, o "retorno"

18 MESTERS, Carlos. Bíblia: livro feito em mutirão. São Paulo: Paulinas, 1986.

19 ALTER, Robert. Introdução ao Antigo Testamento. In: ALTER, Robert; KERMODE, Frank (Orgs.). Guia literário da Bíblia. São Paulo: Fundação Editora da UNESP, 1977. p. 25. 
a uma terra que ela nunca viu antes, e retorno porque é agora sua terra por escolha. ${ }^{20}$

Na Bíblia, a atualização se apresenta em múltiplas formas.

\section{A narrativa a partir das pessoas}

No filme "Narradores de Javé", a narrativa a partir das pessoas não se dá somente porque elas atualizam os feitos heroicos do passado a partir de suas próprias vivências, mas também porque à narrativa principal juntam-se outras narrativas sem um vínculo explícito com essa narrativa principal e porque as pessoas podem narrar suas vivências a seu modo.

Quando o filme retrata a visita de Antônio Biá ao Gêmeo e ao Outro, ouve uma narrativa cujo único vínculo com a figura de Indalécio é que seus ossos estão sepultados nas terras deles. Antônio Biá quase sempre está acompanhado de uma comitiva de moradores do povoado e, quase por um acaso, chegam à casa de Daniel. Ali, ouvem outro testemunho: uma narrativa de pobreza, sofrimento e apego à figura do pai, de nome Isaías, e que se transforma em apego ao lugar. A narrativa a partir das pessoas - porque pessoas importam - também é nítida no modo de narrar do líder da comunidade negra, que fala em sua língua e mescla fala e canto.

Há algum tempo, as qualidades literárias do texto bíblico começaram a despertar o interesse de alguns críticos de literatura. Um dos marcos nesse percurso foi a publicação, em 1946, de Mimesis, de Erich Auerbach, para quem a literatura do Ocidente se funda sobre dois únicos paradigmas: a Odisseia e a Bíblia. Para ele, o gênio narrativo bíblico mostra-se superior. Em boa parte, essa superioridade provém, segundo ele, do modo como se dá a construção das personagens na Bíblia. A seu modo, o então professor da Universidade Católica Portuguesa, José Tolentino Mendonça assim representa as observações de Auerbach a esse respeito:

Na Bíblia, o enquadramento social é mais extenso e diversificado. São heróis o rei e o servo; o sacerdote, o profeta, a mulher, o guerreiro e o pastor. Todos os componentes da sociedade aparecem representados. $E$

20 ALTER, Robert. Introdução ao Antigo Testamento. In: ALTER, Robert; KERMODE, Frank (Orgs.). Guia literário da Bíblia. São Paulo: Fundação Editora da UNESP, 1977. p. 26. 
o sublime tem por expressão um realismo quotidiano, inserido no plano da vida comum. ${ }^{21}$

Por sua vez, o biblista Jean-Louis Ska, exímio professor do Pontifício Instituto Bíblico de Roma, aponta quatro características básicas da literatura antiga, na qual encontra-se também a Bíblia. São elas: (1) a lei da antiguidade ou da precedência, segundo a qual "o que valia eram as coisas antigas",22 (2) a lei da conservação, segundo a qual "nada se elimina", ${ }^{23}$ de modo que uma tradição, ainda que superada, não será eliminada, mas corrigida e interpretada; (3) a lei da continuidade ou da atualidade, de acordo com a qual "a tradição conserva apenas o que tem valor para o presente", ${ }^{24}$ (4) a lei da economia, de acordo com a qual "escreve-se apenas o necessário". ${ }^{25}$

Em "Narradores de Javé", há uma cena em que as narrativas se bifurcam em duas versões, a de Deodora e a de Firmino. Há uma votação para se decidir qual das duas será escrita, na qual dona Maria vota duas vezes, nas duas narrativas, justificando seu voto duplo porque "as duas histórias têm sentido, não se pode tirar uma sem prejuízo da outra". Na Bíblia também é assim, a pluralidade de narrativas antes de ser uma imperfeição é uma qualidade. Se essas narrativas apresentam contradições entre si, cabe ao leitor resolvê-las, caso não possa conviver com elas, mas não cabe ao editor - ou não deveria caber - privar o leitor do acesso a todos os pontos de vista possíveis que os diversos narradores lhe propõem.

A questão da multiplicidade de narrativas também tem repercussão na tão debatida questão da História de Israel. No Brasil, quem trabalha esse tema é o professor Airton José da Silva. Em um artigo sobre o debate atual sobre a História de Israel, depois de ter apresentado as posturas maximalista, segundo a qual tudo o "que não pode ser provado como falso deve ser aceito como histórico" ${ }^{26} \mathrm{e}$ minimalista, segundo a qual tudo o que não pode ser corroborado por evidências contemporâneas [...] deve

21 MENDONÇA, José Tolentino. A leitura infinita: Bíblia e interpretação. Lisboa: Assírio \& Alvim, 2008. p. 33.

22 SKA, Jean Louis. Introdução à leitura do Pentateuco: chaves para a interpretação dos primeiros cinco livros da Bíblia. São Paulo: Loyola, 2003. p. 179.

23 SKA, 2003, p. 183.

24 SKA, 2003, p. 184.

25 SKA, 2003, p. 187.

26 SILVA, Airton José. A história de Israel na pesquisa atual. In: FARIA, Jacir de Freitas. História de Israel e as pesquisas mais recentes. 2. ed. Petrópolis: Vozes, 2003. p. 73. 
ser descartado", ${ }^{27}$ aventa que ambas as posturas dependem, em última instância da compreensão positivista da história. O futuro, por sua vez, pertence à história narrativa. ${ }^{28}$

Quando Antônio Biá ouve o testemunho do líder da comunidade negra, ele se irrita porque o testemunho é interrompido por cantorias. Samuel, que conduziu Biá até lá, explica: "Ele tá contando do jeito dele". A Bíblia também tem seu jeito de contar, muitas vezes interrompendo as narrativas para a inserção de cânticos. É assim que após a narrativa da passagem do mar Vermelho, em Ex 14, vem o cântico da vitória, em Ex 15. Isso também mostra a importância da pesquisa sobre os gêneros literários nos estudos bíblicos. Tal importância também foi sublinhada na Constituição Dogmática Dei Verbum, quando afirma que "[p]ara descobrir a intenção dos hagiógrafos, devem ser tidos também em conta, entre outras coisas, os 'gêneros literários"” $(\mathrm{DV}, 12){ }^{29}$

Essa polifonia da Bíblia possibilita que as pessoas a leiam para aprender a narrar suas próprias histórias. De acordo com Kinno A. Cerqueira, membro do CEBI, “[a]o lermos as histórias da Bíblia, descobrimo-las como sendo nossas próprias histórias...${ }^{30} \mathrm{O}$ autor prossegue:

Isto se explica por ser a Bíblia um genuíno textus (lat.), isto é, uma colcha de muitas cores formada mediante o entrelaçamento de fios coloridos e diversos; um texto de muitos textos falantes e andarilhos; um mosaico de utopias e esperanças, de carne e sangue, de desejos e sonhos, enfim, de gente como a gente... À medida que a leitura da Bíblia nos ajuda a descobrir a natureza textual de nossas próprias vidas, damo-nos conta de que ler a Bíblia é sempre uma experiência de intertextualidade, uma vez que inaugura o encontro do texto de papel, que é a Bíblia, com o texto de carne, que somos nós. ${ }^{31}$

Narrar a própria história a partir das narrativas bíblicas é caminho para descobrir a presença de Deus em nossas vidas.

\footnotetext{
$27 \quad$ SILVA, 2003, p. 73.

28 SILVA, 2003, p. 81.

29 CONCÍLIO VATICANO II. Constituição Dogmática Dei Verbum, sobre a revelação divina. Disponível em: <https://www.vatican.va/archive/hist_councils/ii_vatican_council/ documents/vat-ii_const_19651118_dei-verbum_po.html>.

30 CERQUEIRA, Kinno Alves. Leitura popular da Bíblia: intuição e prática. In: Anais Eletrônicos do V Simpósio Cristianismo e Interpretações. Recife: Universidade Católica de Pernambuco, 30 e 31 de outubro de 2019; p. 22.
} 


\section{Onde está a história}

Na cena final, Zaqueu - mais uma personagem do filme com nome bíblico - diz que "desde, então, é essa a história de Javé que se conta e que também pode ser lida e relida por essas grotas e serras sem fim". Essa fala mostra que a tradição escrita não substitui a tradição oral, mas soma-se a ela, cada qual com suas características próprias. Lembrando que todo o filme é uma narração de Zaqueu, uma narrativa que engloba diversas narrativas, em linguagem cinematográfica.

Que a tradição escrita não substitui a tradição oral, mas soma-se a ela também se pode perceber na Bíblia, o que fica mais claro a partir da relação entre povo de Deus e Bíblia. Antes da Bíblia, já existia o povo de Deus; durante todo o processo de redação da Bíblia, estava ali o povo de Deus; quando se terminou de escrever a Bíblia e foi fixado o cânon de seus escritos, também ali estava o povo de Deus. Assim, a Bíblia não é uma coleção de máximas reveladas a uma pessoa iluminada, mas o registro escrito da caminhada de Deus com seu povo.

Isso significa, em primeiro lugar, que o povo de Deus forma um círculo hermenêutico em torno da Bíblia. A interpretação da Bíblia se dá no interior desse círculo hermenêutico. Coube a Irineu de Lião a formulação do primeiro princípio básico de interpretação da Bíblia, chamado de regula fidei e expresso no Credo apostólico (Haer. I, 10,1). ${ }^{32}$ "Este princípio, confessado no batismo e transmitido pela tradição não explica a Escritura, mas dá o enquadramento dentro do qual uma interpretação deve manter-se para poder ser considerada eclesialmente verdadeira". ${ }^{33}$

Esse primeiro círculo hermenêutico abre-se para um segundo círculo hermenêutico que é a fé comum de cristãos e judeus no mesmo Deus único, sendo a Bíblia Hebraica/Antigo Testamento a base comum de Escritura compartilhada por uns e outros. Embora haja diferentes perspectivas de interpretação dessa base comum de Escritura, não se pode menosprezá-la, nem esquecer que o Novo Testamento, próprio dos cristãos, refere-se, sem cessar, ao patrimônio da "Sagrada Escritura de Israel", como afirma o documento O povo judeu e as suas Sagradas

32 IRENEU de Lião. Contra as heresias. São Paulo: Paulus, 1995. p. 61-62.

33 MALZONI, Cláudio Vianney. A hermenêutica bíblica: entre a hermenêutica do texto e a hermenêutica do ser. Revista Dominicana de Teologia. São Paulo, ano III, n. 6, p. 7-30, 2008; p. 11. 
Escrituras na Bíblia cristã, da Pontifícia Comissão Bíblica, em seu número $11 .^{34}$

Há ainda um terceiro ciclo hermenêutico constituído por todas as pessoas, uma vez que a Bíblia é destinada a toda a humanidade e crentes e não crentes podem nela encontrar uma palavra de encorajamento para suas vidas, dirigindo-as para a prática do bem. Tal encorajamento não é automático, nem emana, necessariamente, da leitura isolada de passagens bíblicas, mas de uma leitura integral e integradora daquele que lê. De fato, a leitura fundamentalista da Bíblia ronda aqueles que se aproximam da Bíblia, não crentes e crentes.

A respeito do fundamentalismo, assim se expressa outro documento da Pontifícia Comissão Bíblica, chamado de $A$ interpretação da Biblia na Igreja:

Ele se recusa em admitir que a Palavra de Deus inspirada foi expressa em linguagem humana e que ela foi redigida, sob a inspiração divina, por autores humanos cujas capacidades e recursos eram limitados. Por esta razão, ele tende a tratar o texto bíblico como se ele tivesse sido ditado palavra por palavra pelo Espírito e não chega a reconhecer que a Palavra de Deus foi formulada em uma linguagem e uma fraseologia condicionadas por uma ou outra época. ${ }^{35}$

Quanto aos efeitos do fundamentalismo, há, no mesmo documento apenas citado, esta afirmação: "Ele se apoia sobre uma leitura não-crítica de certos textos da Bíblia para confirmar ideias políticas e atitudes sociais marcadas por preconceitos, racistas, por exemplo, simplesmente contrários ao Evangelho cristão". ${ }^{36}$

A interpretação da Bíblia na Igreja foi um marco importante nos estudos bíblicos. Depois de tratar dos métodos para a interpretação da Bíblia, trata dos diversos tipos de abordagens da Bíblia: abordagens baseadas na Tradição, abordagens através das ciências humanas e abordagens contextuais. Dentre as abordagens contextuais, menciona duas: a abordagem da libertação e a abordagem feminista. ${ }^{37}$ Essa breve relação

34 PONTIFÍCIA COMISSÃO BíBLICA. O povo judeu e as suas Sagradas Escrituras na Bíblia cristã. São Paulo: Paulinas, 2012. p. 35.

PONTIFÍCIA COMISSÃO BÍBLICA. A interpretação da Bíblia na Igreja. Petrópolis: Vozes, 1994. p. 63. 
pode ser atualizada, incluindo-se nela, entre outras, a abordagem a partir da ecologia integral e a abordagem a partir das questões multiculturais; ambas interessariam, por exemplo, aos povos indígenas, para mencionar uma expressão tão amada por uns, mas odiada por outros.

As abordagens contextuais levantam questionamentos que são pertinentes. Aqueles que os colocam situam-se no primeiro círculo hermenêutico mencionado acima, ou seja, partem de sua vivência eclesial da fé e de sua experiência de opressão devido às situações que enfrentam: enquanto empobrecidos, enquanto mulheres, enquanto povos culturalmente subjugados, enquanto natureza devastada, enquanto alguns aos quais se pede sacrifício em vista do progresso de muitos, como é o caso das populações atingidas pela construção de barragens, drama tão bem retratado em "Narradores de Javé".

O bom entendimento da relação entre tradição oral e tradição escrita ajuda a afastar o risco do fundamentalismo, pois evita que o escrito seja absolutizado e insere sua leitura no contexto de povo de Deus, submetendo as interpretações individuais ao julgamento comunitário, que pode aprová-las, melhorá-las ou descartá-las pelo esquecimento.

A relação entre tradição escrita e tradição oral inscreve-se no horizonte mais amplo da relação entre Escritura e Tradição. A esse respeito, pode-se encontrar a seguinte afirmação no documento $O$ povo judeu $e$ as suas Sagradas Escrituras na Bíblia cristãa:

O cristianismo partilha com o judaísmo a convicção de que a revelação de Deus não pode ser expressa completamente nos textos escritos. Essa convicção é manifestada no final do quarto evangelho, onde se diz que o mundo inteiro não poderia conter os livros que seria necessário escrever para narrar todas as coisas feitas por Jesus (cf. Jo 21,25). Por outro lado, a Tradição vivente é indispensável para vivificar a Escritura e atualizá-la. ${ }^{38}$

Em "Narradores de Javé", há um símbolo que atravessa toda a narrativa: o sino, unindo passado, presente e futuro. É o sino da igreja onde as pessoas se reuniam. Com a devida permissão do pleonasmo, é um símbolo que congrega. Em linguagem teológica, é um símbolo eclesial.

38 PONTIFÍCIA COMISSÃO BÍBLICA, 2012, p. 33. 


\section{Considerações finais}

Esse percurso procurou mostrar não apenas o quanto o filme "Narradores de Javé" é uma obra de qualidade, como também serve para provocar o debate em várias áreas do conhecimento. Lançado em 2003, o filme mantém sua atualidade. Uma simples pesquisa na internet já é suficiente para mostrar o quanto o filme tem sido usado por professores de história em suas aulas. A busca no catálogo de teses e dissertações da CAPES mostra que também serviu de base para estudos na área das ciências da linguagem. Este artigo quis mostrar que o filme também pode ajudar na compreensão de diversos temas nos estudos bíblicos, alguns dos quais bastante complexos. Para isso, foram levantados quatro temas ou campos do estudo, o primeiro e o quarto próximos entre si, assim como o segundo e o terceiro.

No primeiro campo, sobre de onde surge a necessidade de escrever, foram assinalados os estudos sobre a possibilidade da existência de tradições orais anteriores às tradições escritas, usando esses termos sempre no plural. Tais estudos entram no campo de investigação do método histórico-crítico, mais precisamente, no estudo das tradições. Tal método foi aplicado, de modo especial, ao Pentateuco, sendo também utilizado nos estudos da formação dos evangelhos. O quarto campo, sobre onde está a história, voltou a tratar das relações entre a tradição oral e a tradição escrita, mas agora a partir de outra perspectiva, aquela de que a tradição escrita não substitui a tradição oral, mas soma-se a ela. Essa questão está relacionada àquela dos círculos hermenêuticos nos quais a Bíblia é interpretada, com destaque para a relação intrínseca entre povo de Deus e Bíblia. As leituras fundamentalistas, em última instância, desprezam essa relação. Em contrário, as abordagens contextualizadas, ainda quando feridas por uma ou outra passagem de um escrito bíblico, repropõem continuamente a leitura por inteiro da Escritura.

No segundo campo, sobre narrar atualizando, viu-se como o método da leitura popular da Bíblia se enquadra bem nessa perspectiva, fazendo a Bíblia voltar para a vida, que é onde se encontra seu ponto de partida. Esse método não aporta um elemento estranho à leitura bíblica, uma vez que a própria Bíblia, sem cessar está se atualizando pelas inumeráveis alusões entre seus escritos. O terceiro campo foi o da narrativa a partir das pessoas, que atraiu a atenção dos críticos de literatura para a Bíblia. O enquadramento social nos quais as personagens das narrativas bíblicas se movem é amplo, de modo que muitas vozes podem ser 
ouvidas. Quando ocorrem narrativas conflitantes, a tendência da Bíblia é apresentá-las ao leitor. Isso tem suas consequências tanto para a construção da História de Israel, que pode desincumbir-se da perspectiva positivista da história, quanto para a leitura popular da Bíblia, que pode oferecer um leque maior de narrativas para as pessoas construírem suas próprias narrativas.

Por todas essas razões, este artigo termina parabenizando a diretora Eliane Caffé, os roteiristas, os atores profissionais e a população de Gameleira de Lapa que atuou no filme. "Narradores de Javé" está disponível no YouTube: $<$ https://www.youtube.com/watch? $\mathrm{v}=$ Trm-CyihYs $8 \& \mathrm{t}=213 \mathrm{~s}>$.

\section{Referências}

ALTER, Robert. Introdução ao Antigo Testamento. In: ALTER, Robert; KERMODE, Frank (Orgs.). Guia literário da Bíblia. Tradução Raul Fiker; revisão de tradução Gilson César Cardoso de Souza. São Paulo: Fundação Editora da UNESP, 1977. p. 23-48.

ARANTES, Silvana. Episódio real inspira "Narradores de Javé". In: Folha de São Paulo, Ilustrada, 17/10/2003. Disponível em: <https:// www1.folha.uol.com.br/folha/ilustrada/ult90u37926.shtml>. Acesso em: 17 maio 2020.

CAPES. Catálogo de teses e dissertações. Disponível em: $<$ https://catalogodeteses.capes.gov.br/catalogo-teses/\#!/>. Acesso em: 17 maio 2020.

CARDOSO, Heloisa Helena Pacheco. Narradores de Javé: história, imagens, percepções. Fênix: Revista de História e Estudos Culturais. Uberlândia, v. 5, n. 2, p. 1-11, 2008. Disponível em: <http://www.revistafenix.pro.br/PDF15/Artigo_04_ABRIL-MAIO-JUNHO_2008_Heloisa_Helena_Pacheco_Cardoso.pdf $>$. Acesso em: 24 maio 2020.

CERQUEIRA, Kinno Alves. Leitura popular da Bíblia: intuição e prática. In: Anais Eletrônicos do V Simpósio Cristianismo e Interpretações. Recife: Universidade Católica de Pernambuco, 30 e 31 de outubro de 2019; p. 21-26. Disponível em: <http://www.unicap.br/ocs/index.php/ simpcris/simpcrisxix/paper/view/1591/395>. Acesso em: 20 maio 2020.

CONCÍLIO VATICANO II. Constituição Dogmática Dei Verbum, sobre a revelação divina. Disponível em: <https:/www.vatican.va/archive/ hist_councils/ii_vatican_council/documents/vat-ii_const_19651118_dei-verbum_po.html>. Acesso em: 28 maio 2020. 
CÔRTES, Norma. História, memória e derrisão em Narradores de Javé. Revue Nuevo Mundo Nuevos Mundos [online], 20 abr. 2010. Disponível em: $<$ https://journals.openedition.org/nuevomundo/59591>. Acesso em: 5 jun. 2020.

ELIANE CAFFÉ. Disponível em: <http://www.elianecaffe.com/curriculo.html>. Acesso em: 16 maio 2020.

EM ENTREVISTA, cineasta Eliane Caffé fala do seu segundo longa, Narradores de Javé. Revista Época, Rio de Janeiro, Globo Editores, edição 296, 19 jan. 2004. Disponível em: <http://revistaepoca.globo. com/Revista/Epoca/0,,EDG62255-5856,00-EM+ENTREVISTA+CIN EASTA+ELIANE+CAFFE+FALA+DO+SEU+SEGUNDO+LONGA +INARRADORES+D.html>. Acesso em: 26 maio 2020.

FILMOW. Narradores de Javé. Disponível em: <https://filmow.com/ narradores-de-jave-t5459/ficha-tecnica/>. Acesso em: 15 maio 2020.

IRENEU de Lião. Contra as heresias. Introdução, notas e comentários Helcion Ribeiro; organização das notas bíblicas Roque Frangiotti; tradução Lourenço Costa. São Paulo: Paulus, 1995. (Patrística, 4).

LIPIŃSKI, Édouard. Tradições, História das. In: Dicionário enciclopédico da Bíblia. Publicado sob a direção do Centro: "Informática e Bíblia", Abadia de Maredsous. Tradução Ary E. Pintarelli, Orlando A. Bernardi. São Paulo: Loyola, Paulus, Paulinas, 2013. p. 1325.

MALZONI, Cláudio Vianney. A hermenêutica bíblica: entre a hermenêutica do texto e a hermenêutica do ser. Revista Dominicana de Teologia. São Paulo, ano III, n. 6, p. 7-30, 2008.

MENDONÇA, José Tolentino. A leitura infinita: Bíblia e interpretação. Lisboa: Assírio \& Alvim, 2008.

MESTERS, Carlos. Bíblia: livro feito em mutirão. São Paulo: Paulinas, 1986.

NARRADORES DE JAVÉ. Disponível em: $<$ http://www.adorocinema. com/filmes/filme-52182/curiosidades/>. Acesso em: 16 maio 2020.

PAPO DE CINEMA. Eliane Caffé. Disponível em: <https://www. papodecinema.com.br/artistas/eliane-caffe/biografia/>. Acesso em: 14 maio 2020.

PONTIFÍCIA COMISSÃO BÍBLICA. A interpretação da Bíblia na Igreja. Petrópolis: Vozes, 1994. (Documentos Pontifícios, 260). 
PONTIFÍCIA COMISSÃO BÍBLICA. O povo judeu e as suas Sagradas Escrituras na Bíblia cristã. 1. reimpressão. São Paulo: Paulinas, 2012. (Documentos da Igreja, 8).

RIBEIRO Júnior, Antônio Carlos Araújo; FEITOSA, Márcia Manir Miguel. Narradores de Javé: memórias e identidades polifônicas no cinema brasileiro. In: Resgate: Revista Interdisciplinar de Cultura. Campinas, v. 25 , n. 1, p. 67-88, 2017. Disponível em: $<$ https://periodicos.sbu.unicamp.br/ojs/index.php/resgate/article/view/8648175/16639>. Acesso em: 03 jun. 2020.

SILVA, Airton José. A história de Israel na pesquisa atual. In: FARIA, Jacir de Freitas. História de Israel e as pesquisas mais recentes. 2. ed. Petrópolis: Vozes, 2003. p. 43-87. Também disponível em: <https:// airtonjo.com/site1/historia-de-israel.htm>. Acesso em: 28 maio 2020.

SKA, Jean Louis. Introdução à leitura do Pentateuco: chaves para a interpretação dos primeiros cinco livros da Bíblia. Tradução Aldo Vannucchi. São Paulo: Loyola, 2003. (Bíblica Loyola, 37). 